\title{
PENERAPAN SISTEM INFORMASI MANAJEMEN PADA PENGAMBILAN KEPUTUSAN MANAJEMEN PT. JAYA BRIX INDONESIA DI LAMONGAN
}

Ike Susanti, Indriana Kristiawati,Ahmad Bayu Sahroni Prodi Manajemen, Fakultas Ekonomi Universitas Islam Lamongan E-mail :Ik33susanti@gmail.com, Indriana_K@yahoo.com

\begin{abstract}
ABSTRAK
Tujuan dari penelitian ini adalah untuk mengetahui Fungsi Dari Sistem Informasi Manajemen Sebagai Dasar Pengambilan Keputusan Bagi Manajer PT.Jaya Brix Indonesia Desa Kemantren Paciran Di Lamongan. Penelitian ini menggunakan metode deskriptif kualitatif. Penelitian ini menggunakan metode analisis data yaitu analisis deskriptif kualitatif karena data yang di kumpulkan berupa kata-kata dan gambar dalam hal ini penulis akan melihat, membaca dan mempelajari bagaimana peranan sistem informasi manajemen dalam pengambilan keputusan bagi manager pemasaran PT. Jaya Brix Kemantren.Hasil penelitian menunjukan bahwa kegiatan pengambilan keputusan bagi manager pemasaran PT. Jaya Brix Indonesia Kemantren tidak maksimal dan tidak efektif, serta volume penjualan mengalami penurunan. Karena dalam penerimaan informasi mengalami keterlambatan dan kekurangan informasi yang dibutuhkan dalam pengambilan keputusan serta pihak perusahaan khususnya di bidang pemasaran tidak dapat memantau dan memonitor secara pasti kegiatan pemasaranya.

Kata Kunci :PenerapanSistem Informasi Manajemen, dan Pengambilan Keputusan
\end{abstract}

\section{PENDAHULUAN}

Saat ini persaingan antara perusahaan yang sejenis semakin ketat yang mana diikuti oleh semakin berkembangnya arus informasi yang selalu berubah dari waktu ke waktu dan secara tidak langsung membuat perusahaan khususnya manajer pemasaran harus lebih berhati-hati dan mampu mengkaji kembali strategi system informasi dalam setiap pengambilan keputusan yang telah ditetapkan dan dijalankan dengan menggunakan informasi yang tepat, relevan dan benar untuk menunjang keberhasilan dalam tercapainya tujuan perusahaan. 
Manajer sebagai seorang yang mengelola dan mengendalikan perusahaan harus memiliki keahlian dan keterampilan tertentu agar tujuan perusahaan dapat tercapai. Untuk itu seorang manajer harus dapat menjalankan fungsi-fungsinya dengan baik, sesuai dengan teknik dan prosedur serta metode yang telah ditetapkan oleh perusahaan dalam menjalankan fungsinya. Selain itu seorang manajer harus belajar banyak tentang teknologi informasi sehingga dia akan memahami informasi apa yang dibutuhkan dan berasal dari mana saja informasi tersebut harus di cari. Sehingga perusahaan akan selalu berusaha mengadakan perbaikan dalam kegiatan pemasaran dan dapat menetapkan berbagai alternatif guna mengurangi ketidakpastian dan mengubah kemungkinan-kemungkinan hasil yang diharapkan dalam pengambilan keputusan.Berdasarkan latar belakang tersebut maka penulis tertarik mengambil judul penelitian : "FUNGSI DARISISTEM INFORMASI MANAJEMEN SEBAGAI DASAR PENGAMBILAN KEPUTUSAN BAGI MANAGER PADA PT. JAYA BRIXINDONESIA KEMANTREN PACIRANDI LAMONGAN"

\section{RUMUSAN MASALAH}

1. Bagaimana Penerapan Sistem Informasi ManajemenPada Pengambilan KeputusanManajemen PT. Jaya Brix Indonesia Di Lamongan?

2. Apakah ada keterkaitan antara Sistem Informasi ManajemenPada Pengambilan Keputusan manajemen PT. Jaya Brix Indonesia Di Lamongan?

\section{TUJUAN PENELITIAN}

1. Untuk Mengetahui Penerapan Sistem Informasi Manajemen Pada Pengambilan KeputusanManajemen PT. Jaya Brix Indonesia Di Lamongan?

2. Untuk Mengetahui Adakah keterkaitan antara Sistem Informasi Manajemen Pada Pengambilan Keputusan manajemen PT. Jaya Brix Indonesia Di Lamongan? 


\section{LANDASAN TEORI}

\section{Pengertian Sistem}

Dalam Era Globalisasi Sistem Informasi Manajemen merupakan bagian yang tak terpisahkan dari suatu organisasi dimana sistem informasi yang menghasilkan hasil keluaran (output) dengan menggunakan masukan (input) dan berbagai proses yang diperlukan untuk memenuhi tujuan tertentu dalam suatu kegiatan manajemen. Menurut (Stoa, 2008) "Pengertian dari sistem merupakan gabungan dari keseluruhan langit dan bumi yang saling bekerja sama yang membentuk suatu keseluruhan dan apabila salah satu unsur tersebut hilang atau tidak berfungsi, maka gabungan keseluruhan tersebut tidak dapat lagi kita sebut suatu sistem".Menurut (Kerz, 2008) "Sistem yaitu gabungan dari sekelompok komponen baik itu manusia dan/atau bukan manusia (non-human) yang saling mendukung satu sama lain serta diatur menjadi sebuah kesatuan yang utuh untuk mencapai suatu tujuan, sasaran bersama atau hasil akhir”.

\section{Pengertian Informasi}

Berikut ini pengertian informasi yang dikemukakan oleh para ahli dalam buku ( Rusdiana, Irfan Moch 2014:74) :

1) MenurutTata Sutabri (2005), menyatakan bahwa "informasi adalah data yang telah diklasifikasikan atau diolah atau diinterprestasikan untuk digunakan dalam proses pengambilan keputusan".

2) Menurut Susanto (2002), "informasi merupakan hasil dari pengolahan data, tetapi tidak semua hasil dari pengolahan tersebut dapat menjadi informasi. Hasil pengolahan data yang tidak memberikan makna atau arti serta tidak bermanfaat bagi seseorang bukanlah informasi bagi orang tersebut".

\section{Pengertian Manajemen}

Menurut Ricky W.Griffin (2002) Manajemen adalah sebuah proses perencanaan, pengorganisasian, pengkoordinasian dan pengontrolan sumber daya untuk mencapai sasaran secara efektif dan efisien. Efektif berarti bahwa tujuan dapat 
dicapai sesuai dengan perencanaan, sementara efisien berarti bahwa tugas yang ada dilaksanakan secara benar, terorganisir dan sesuai dengan jadwal.

Menurut George R.Terry (2003) Manajemen adalah proses yang khas yang terdiri dari tindakan - tindakan : perencanaan, pengorganisasian,penggerakan, dan pengawasan yang dilakukan untuk menentukan serta mencapai sasaran sasaran yang telah di tetapkan melalui pemanfaatan sumber daya manusia serta sumber yang lain. Manajemen adalah wadah didalam ilmu pengetahuan, sehingga manajemen bisa dibuktikan secara umum kebenarannya.

\section{Pengertian Sistem Informasi Manajemen}

Menurut O'Brien (dalam Rusdiana, Irfan Moch 2014 : 94 ), merumuskan sistem informasi manajemen adalah :"Sistem terpadu yang menyediakan informasi untuk mendukung kegiatan operasional, manajemen, dan fungsi pengambilan keputusan dari suatu organisasi”.

\section{Pengambilan Keputusan}

Fungsi dari pengambilan keputusan Rochaety (2013 : 115):

a. Pangkal permulaan dari semua aktivitas manusia yang sadar dan terarah, baik secara individual maupun secara kelompok, baik secara institusional maupun secara organisasional.

b. Sesuatu yang bersifat futuristik, artinya bersangkut paut dengan hari depan, masa akan datang, dimana efeknya atau pengaruhnya berlangsung cukup lama.

Tujuan pengambilan keputusan menurut Rochaety (2013 : 115):

a. Tujuan yang bersifat tunggal, terjadi apabila keputusan yang dihasilkan hanya menyangkut satu masalah, artinya bahwa sekali diputuskan, tidak akan ada kaitanya dengan masalah lain.

b. Menurut tujuan yang bersifat ganda, terjadi apabila keputusan yang dihasilkan itu menyangkut lebih dari satu masalah, artinya bahwa keputusan yang diambil itu sekaligus memecahkan dua masalah (atau lebih), yang bersifat kontradiktif atau yang tidak kontradiktif. 


\section{HIPOTESIS}

H1 :Diduga bahwa ada Penerapan Sistem Informasi Manajemen Pada Pengambilan Keputusan Manajemen PT. Jaya Brix Indonesia Di Lamongan?

H2 : Diduga bahwa ada keterkaitan antara Sistem Informasi Manajemen Pada Pengambilan Keputusan manajemen PT. Jaya Brix Indonesia DiLamongan?

\section{METODE PENELITIAN}

Dengan pedoman pada latar belakang dan rumusan masalah penelitian serta berlandasan pada teori-teori yang telah di uraikan sebelumnya maka penelitian yang di gunakan adalah penelitian diskriptif/kualitatif atau penelitian uji hipotesa. Menurut Moleong (1998) dalam buku Arikunto (2013 : 22), penelitian diskriptif/kualitatif adalah tampilan yang berupa kata-kata lisan atau tertulis yang dicermati oleh peneliti, dan benda-benda yang diamati sampai detailnya agar dapat ditangkap makna yang tersirat dalam dokumen atau bendanya.

Dalam penelitian jenis ini hipotesis yang telah di rumuskan diuji yang mengetahui adanya peranan atau variable-variable dalam penelitian mengenai sistem informasi manajemen yang sangat beperan dalam pengambilan keputusan bagi manajer pemasaran pada suatu perusahaan.

\section{Teknik Penarikan Sampel}

1. Populasi

2. Sampel

3. Teknik Pengambilan sampel

\section{Metode Pengumpulan Data}

1. Sumber Data

2. Pengumpulan Data

3. Study Literatur 


\section{Metode Analisis Data}

Analisis data yang dilakukan dengan mengelolah data yang diperoleh berdasarkan teori dengan membandingkan keadaan yang sebenarnya terjadi dalam perusahaan. Metode analisis data yang di gunakan adalah analisis Deskriptif Kualitatif karena data yang dikumpulkan berupa kata-kata, gambar, dan bukan hitungan dalam hal ini penulis akan melihat, membaca dan mempelajari bagaimana Fungsi Sistem Informasi Manajemen Dalam Pengambilan Keputusan Bagi Manajer Pemasaran PT. Jaya Brix Indonesia Kemantren Paciran Lamongan. Menurut Suryabrata (2010 : 18), "penelitian deskriptif kualitatif adalah penelitian yang bermaksud untuk mengidentifikasi masalah-masalah atau untuk mendapat keterangan suatu keadaan dari praktek-praktek yang sedang berlangsung dalam suatu perusahaan”.

\section{HASIL ANALISIS DATA}

Adapun masalah yang sedang dihadapi oleh perusahaan PT. Jaya Brix Indonesia Kemantren Paciran Lamongan adalah "Fungsi Sistem Informasi kurang efektif dan tidak dapat menunjang Dalam Pengambilan Keputusan”. Hal ini disebabkan karena kurang lengkapnya informasi yang masuk ke manejer pemasaran sehingga mengakibatkan rencana pengambilan keputusan tidak dapat dilaksanakan sesuai waktu yang ditentukan dan menurunya tingkat volume penjualan baik kepada agen maupun konsumen.

\section{PEMBAHASAN}

\section{Sebab Masalah}

Adapun sebab permasalahan yang terjadipada perusahaan ini adalah sebagai berikut:

1. Kurang terampilnya tenaga penjual untuk memperoleh dan melaporkan informasi mengenai perkembangan kegiatan pemasaranya.

2. Perusahaan kurang baik dalam menjalin hubungan kerjasama dengan agen. 


\section{Akibat Masalah}

1. Kegiatan pengambilan keputusan yang dilakukan tidak maksimal dan tidak efektif.

2. Volume Penjualan Mengalami Penurunan

Kembali pada masalah yang terjadi di perusahaan ini, akibat lain yang didapat perusahaan PT. Jaya Brix Indonesia Kemantren Paciran Lamongan adalah menurunya tingkat volume penjualan perusahaan. Hal ini disebabkan karena pihak perusahaan khususnya manajer pemasaran tidak dapat memantau, memonitor secara pasti kegiatan pemasarannya sehingga mempengaruhi dalam penetapan kebijakan baru yang berhubungan dengan kegiatan penjualan dan perolehan informasi mengenai kegiatan penjualan atau pemasaran tidak dapat diperoleh dengan pasti, akibatnya tingkat volume penjualan perusahaan menurun.

Sebagai bukti adanya penurunan volume penjualan pada PT. Jaya Brix Indonesia Kemantren Paciran Lamongan pada table berikut:

Table 5.1

Data target dan realisasi Penjualan

PT. Jaya Brix Indonesia Kemantren Paciran Lamongan

\begin{tabular}{|l|l|l|l|l|}
\hline Tahun & $\begin{array}{c}\text { Target } \\
\text { Penjualan }\end{array}$ & $\begin{array}{c}\text { Realisasi } \\
\text { Penjualan }\end{array}$ & Deviasi & \% \\
\hline 2013 & 252 & 252 & - & - \\
2014 & 280 & 265 & 15 & 5,95 \\
2015 & 301 & 294 & 7 & 2,64 \\
2016 & 255 & 237 & 18 & 6,12 \\
2017 & 242 & 217 & 25 & 9,80 \\
& & & & \\
\hline
\end{tabular}

Sumber : PT. Jaya Brix Indonesia 
Dari data tersebut di atas, dapat disimpulkan bahwa untuk penjualan tahun 2014 mengalami deviasi sebesar 15 buah atau sebesar 5,95\%. Demikian pula pada tahun 2015 mengalami deviasi sebesar 7 buah atau 2,645

Akan tetapi pada tahun 2016 volume penjualannya mengalami deviasi sebesar 18 buah atau 6,12\% dan disusul tahun 2017 volume penjualan juga mengalami deviasi lebih dari drastic sebesar 25 buah atau 9,80\%.

Dari table diatas, maka dapat dilihat total volume penjualan mulai tahun 20142018 terus mengalami penurunan.

Sehingga dari sini dapat disimpulkan bahwa perusahaan ini benar-benar mengalami masalah yang mengakibatkan menurunya tingkat penjualan dan hal ini perlu segera diatasi atau mendapatkan pemecahan.

\section{Langkah-langkah Pemecahan Masalah}

Sebagai pemecahan terhadap masalahyang sedang dihadapi pada perusahaan PT. Jaya Brix Indonesia , maka langkah-langkahyang harus dilakukan adalah:

1. Meningkatkan tingkat pendidikan dan keterampilan tenaga penjual untuk meningkatkan kualitas intelgen pemasaran.Dalam usaha meningkatkan produktivitas dan efisiensi, perusahaan PT. Jaya Brix Indonesia dalam menjalankan aktivitasnya perlu memperhatikan peningkatan tingkat pendidikan dan keterampilan tenaga penjual. Hal ini sangat mempengaruhi dalam rangka meningkatkan kepribadian dan keahlian yang semua dimiliki tenaga penjual demi mencapai tujuan perusahaan baik tujuan jangka pendek maupun tujuan jagka panjang.

2. Pemberian Pelatihan dan Pengembangan.Selain pemahaman dan penguasaan dari tugas dasar integen pemasaran, hal yang perlu diberikan kepada para karyawan khusunya tenaga penjual adalah pemberian latihan dan pengembangan keterampilan untuk kegiatan penjualan/pemasaran dan kegiatan pengumpulan dan perolehan informasi dari lingkungan pemasaran perusahaan yang berguna dalam pengambilan keputusan. 


\section{Gambar 5.3}

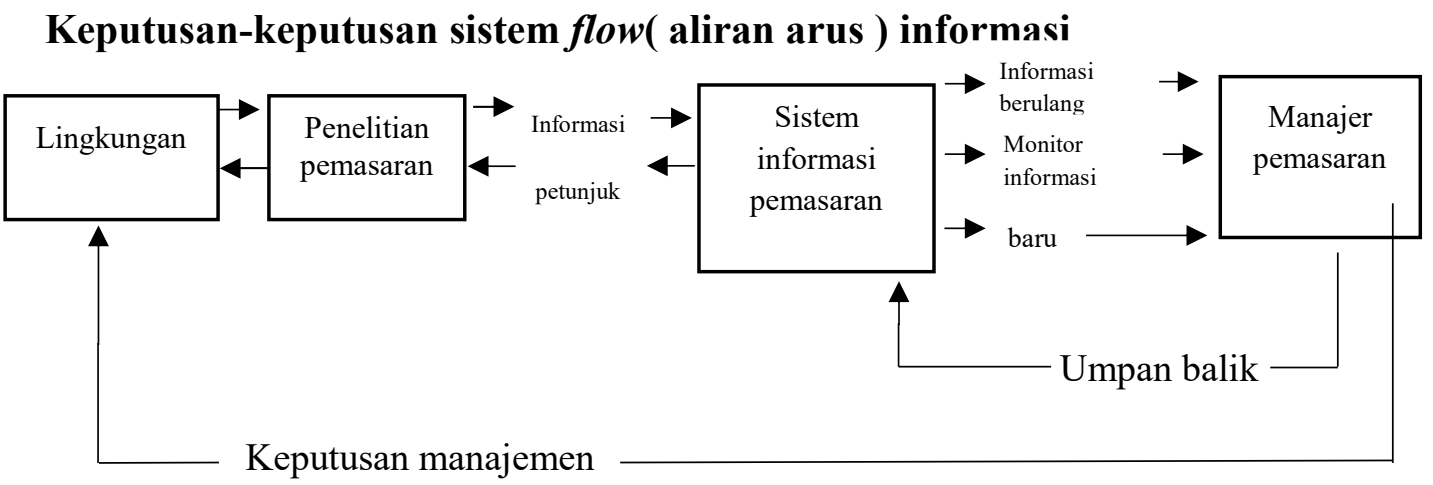

Sumber : Marwan Asri (1991:70)

Informasi-informasi yang lengkap akan diperoleh dari luar(lingkungan) perusahaan dengan melakukan penelitian. Sebagai hasilnya informasi-informasi yang dikumpulkan itu dilanjutkan untuk di salurkan dengan informasi-informasi yang ada sebelumnya, sebagai dasar pengambilan keputusan-keputusan pemasaran oleh manajer pemasaran, yang diharapkan pula untuk memberikan umpan balik terhadap sistem informasi yang membantunya.

\section{KESIMPULAN DAN SARAN}

\section{KESIMPULAN}

1. Dalam pengambilan keputusan, perusahaan mengalami kekurangan informasi yang masuk, khususnya informasi tentang kegiatan pemasaran dan perkembangan baru yang terjadi diluar di pasar, yang disebabkan kurang efektifnya sistem informasi sehingga pengambilan keputusan tidak efektif. Hal ini disebabkan karena semua pihak dalam perusahaan kurang bekerja sama dengan retailer maupun agen, serta kurang terampilnya tenaga penjual dalam perolehan tentang informasi penjualan. Oleh karena itu kekurangan informasi yang masuk, menyebabkan pengambilan keputusan tidak efektif dan menurunya tingkat penjualan. 
2. Manajer sering di hadapkan kepada masalah pengambilan keputusanterutama untuk menentukan kebijakan dan strategi dalam sistem informasi manajemen untuk menentukan keputusan yang tidak dapat menimbulkan resiko.

\section{SARAN}

1. Perusahaan harus mengikuti perkembangan yang ada dalam sistem informasi manajemen, sehingga perusahaan lebih memahami keadaan pasar yang sebenarnya dan dapat menetapkan kebijakan yang baik.

2. Perusahaan khususnya manajer melalui sistem Informasi Manajemen harus melakukan riset terhadap konsumen untuk dapat, mengumpulkan dan menemukan data dan menganalisa dengan situasi pemasaran yang sedang dihadapi perusahaan sehingga masukan-masukan dari konsumen yang bisa dijadikan suatu data mengenai kegiatan penjualan dapat di peroleh.

\section{DAFTAR PUSTAKA}

Arikunto, Suharsimi. 2013. Prosedur Penelitian. Cetakan Ke 15, Jakarta: PT. Rineka Cipta

George R.Terry, Prinsip -Prinsip Manajemen . 2003. Edisi 11. Jogjakarta:Bumi Aksara

Pengambilan Keputusan Bagi Manajer Pemasaran Pada CV. Meta Jaya Kemantren Paciran Lamongan. Lamongan : Universitas Islam Lamongan Ricky W. Griffin , Bisnis. 2002. Jilid 1. Jakarta : Erlangga

Rochaety, Eti. Ridwan Z.Faizal. Setyowati, Tupi. 2013. Sistem Informasi Manajemen Edisi 2. Jakarta: Mitra Wacana Media

Rusdiana. Irfan, Moch. 2014. Sistem Informasi Manajemen. Cetakan I, CV Pustaka Setia 